\title{
Does customer service matter? A customer perception of bank services in Islamic countries
}

\author{
${ }^{1}$ Alshahrani Meshal Saeed $S,{ }^{2}$ Alshahrani Bander Sayaf Z, ${ }^{1}$ Alshahrani Ahmed Saeed A \\ ${ }^{1}$ School of Management, Wuhan University of Technology, Wuhan, P.R. China \\ ${ }^{2}$ Dental department, Armed Forces Hospital, Sharurah city, Saudi Arabia
}

\begin{abstract}
This paper aims to explore the possible usefulness of a combined multi-attribute and SERVQUAL service quality model in analyzing how bank customers perceive service quality. Using a survey, the authors measured how customers in one region in a major Saudi Arabia bank perceived service quality. Responses were analyzed with reference to both multi-attribute service quality and SERVQUAL models. The combined model seems to provide some guidance regarding how bank customers perceive service quality. The finding of several items reveals that customers are difficult to please. However, substantial heterogeneity exists in customer perceptions of the service quality items investigated. This exploratory study examines only one bank in specific region in Saudi Arabia, implying a need for additional research applying this combined model and other methods to investigate banking segment. The noticeable spread in conceptions of service quality items suggests that bank managers and personal bankers may benefit from co-creating services with customers. Banks are considered as intermediates on financial markets. Therefore, improved and customized service quality could make customers inclined to invest their resources in ways that promote economic growth. In addition to traditional measurement models, the SERVQUAL may contribute to service quality assessment in private banking.
\end{abstract}

Key words: Saudi Arabia, Customer Services Quality, Banking, Private Banking, CRM

\section{INTRODUCTION}

Nowadays service quality is essential to determine company's competitiveness more than ever before. Service quality can help companies to distinguish themselves from other organizations and achieve competitive advantage. Superior service quality is a key to improved profitability (Ghobadian et al., 1994). There is an existing demand for service research in Saudi Arabia so companies have opportunity to enter new stages of competition at this time globalization. It is nowadays impossible to avoid quality related issues since it is at the core of each organization that aims for long-term operation and development.

Companies of financial service sector in Saudi Arabia are showing instability in delivering expected service and value for their customers. Saudi Investment Bank is one of such units that is striving for providing better service; understanding service quality concerns. Banks that perform better in quality service can gain better chance to improve their position on the market. Because enhanced degree of service quality determine greater profits, bigger selling ratios of an additional product and service to customer, higher consumer retention (Bennett and Higgins, 1988) and an increased share of market (Bowen and Hedges, 1993). Providing a high quality service brings greater customer retention rates, attracts new customers with a help of word of mouth advertising, boosts productivity, help market shares increase, reduces employee renewal rate and cost of resources, increases employee confidence, enthusiasm and discipline, and generates more profit (Julian and Ramaseshan, 1994; Lewis, 1989, 1993).Thus, providing quality service to customers is a requisite for success and it is must in competitive banking industry ( Samli and Frohlich,1992).

Recent works in this domain illustrate that there are different points of view about how to measure service quality. Many questions were addressed concerning the principles on which instruments to be used. One of the most prevalent service quality measurement tool SERVQUAL has been used and assessed successfully in many sectors of industries. However, we cannot assume it to be an effective in pursuit of universal measurement for wide range of service sectors. Choosing instrument that is designed particularly for aimed industry can be more practical.

It might be against this setting that a new instrument for measuring service quality has been created and empirically tested. And it shapes the foundation for capturing the accurate factors of service quality in the banking sector. Customers are now more demanding in their different relationship with their suppliers; managing a close relationship has become a central aspect in achieving business goals (Xu Yen et al, 2002). With the increase in technology available to customers today, the world has become a 
much smaller marketplace and the relationship has become an important selling aspect. Walton and Xu (2005) explain that customer relationship management (CRM) is widely regarded as method of retaining and developing customers through increased loyalty and satisfaction.

It is for sure that the perception that the company feels by observing its customer is not as precious as customer's own perception. According to Robbins and Al (2006), the company must hold a regular discussion group of loyal customers; it has to send a monthly survey to this group to ask for ideas and comments on how the company can improve its customer service. To do so, the company has to give them a reward or incentive. As part of the process of improving customer service, one should never underestimate the power of details as they can differentiate one's company in the competition. We must "test" the customer on a regular basis. The aim of the present paper is to find the connection between customer satisfactions in Saudi Arabia with six dimensions of service quality. The aim of this study is to observe how the customer satisfaction is influenced by service quality of Islamic banks based on CARTER Islamic bank service quality model (Othman and Owen, 2002).

\section{LITERATURE REVIEW}

\section{SERVICE QUALITY AND CULTURE}

Conceptual model of Parasuraman et.al. (1998), suggests that customer expectations play an important role in service mechanism. Authors also commented that communication, personal needs and past experience form an environment for setting up normative assumptions. Nevertheless, Parasuraman et.al. (1998) did not take into account factors of culture and personal value that constitutes a core of society and reflects on their behavior. These characteristics have been in the attention of critical observation in its exploration of application in different culture context (Malhotra et.al., 1994; Winsted, 1997; Donthu and Yoo, 1998; Furrer et al., 2000; Imrie et al., 2000).

Understanding how costumers in different cultural markets assess service quality can bring valuable information for marketing practitioners. Clear definition of service quality could facilitate tactics to be used in order to tackle threats encountered by a company and find suitable solution to an existing issue. Culture can be identified as ideas, behaviors, attitudes and traditions that exist within large groups of people. We contend that ideas and attitudes of people can give brief insights to consumer behavior. As literature focusing on product marketing supports this argument, further research should be conducted in the field of service. Daunt \& Yoo (1998) and Furrer et.al., (2000) have empirically showed that there is relationship between cultural attributes and hierarchy with which consumers perform an evaluation.

\section{SHARIA COMPLIANT SERVICES}

Research conducted for two decades on banks showed fast, effective service, status, image and pricing to be significant for all. For this study, Islamic banks were primarily chosen for religious motives. Of twelve studies in the Islamic world, eight reported a positive relationship that the provision of Islamic products and services was the main factor influencing customers' patronage. In Islamic countries, many people prefer to invest their money in corporations that pay Zakat (an Islamic religious tax) and they prefer to support banks that do not pay or receive interest on loans.

Recent research results (after 1992) are related to availability and wide use of Islamic bank services due to recent international expansion. What literature says is that Islamic banks must offer quality services while maintaining their Islamic reputation and credentials through offering Sharia compliant services.

The findings of recent studies in various countries do support religion as either the most significant factor or one of the important factors motivating the patronage of Islamic banks products and services (Omer, 1992; Metwally, 1996; Hegazy, 1995; Heron et al., 1994; Metawa and Almossawi, 1998; Nasser, 1999; Al Sultan, 1999). Banks should also embrace good customer service policies to gain full potential as a strategic tool to achieve competitive advantage, secure customers allegiance and improve reputation. To author's knowledge, no research before has been done on the relationship of Sharia compliant services and financial performance.

\section{CARTER (ISLAMIC SERVQUAL)}

Scholars and quality scholars have recognized the need to develop valid and distinct measures of service quality given the rise of service development in the last few decades. SERVQUAL has indeed proved to be the most popular instrument for measuring service quality because it employs techniques used in technology. This is based on the fact that because of the different studies in different service categories, such as banking, telephone services, dentistry, fast food, dry cleaning and credit cards companies, researchers have identified SERVQUAL dimensions on the bases of the firm's culture, products and services, technology and environment. Othman (2003) linked service quality to customer satisfaction and 
customer loyalty reporting that a satisfied customer will be loyal to the organization which is a measure for organizational performance.

CARTER is a model based on the five SERVQUAL dimensions in addition to new dimension called "Compliance with Islamic law" suitable for the Islamic banking industry (Islamic house of Kuwait). This dimension includes items such as "business on Islamic law and principles", "no interest paid or taken on savings and loans", "provision of Islamic products and services", "provision of free interest loans" and "provision of profit sharing investment products". CARTER includes items across six dimensions; compliance, assurance, reliability, tangibles, empathy and responsiveness. To the best of the researcher knowledge, CARTER is the most well-known model in Islamic banking system and has been adopted in many subsequent studies on Islamic banks in different countries (Shafie, Azmi and Haron, 2004, Ciptono and Soviyanti, 2007). These studies on service quality in Islamic banks have, however, tended to be conducted in eastern and predominantly, Muslim-based countries.

\section{SAUDI INVESTMENT BANK}

The Saudi Investment Bank provides wholesale, retail and commercial banking products in the Kingdom of Saudi Arabia. The company arranges financing of government and private industrial sectors and offers trade finance products for facilitating imports and increasing Saudi exports. It also provides a range of Sharia compliant products and services, including accounts, murabaha investments and personal finance solutions. The company operates in retail banking, corporate banking, treasury and asset management and brokerage segments. The retail banking segment provides loans, deposits and other credit products for individuals and small to medium-sized businesses. The corporate banking segment offers loans, deposits and other credit products for corporate and institutional customers. The treasury segment provides money market services, investments and other treasury services. The asset management and brokerage segment is involved in dealing, managing, advising and custody of securities services. The Saudi Investment Bank offers its products and services through approximately 48 branches. The company was founded in 1976 and is headquartered in Riyadh, Saudi Arabia.

The Saudi Investment Bank is a state-owned Bank and it plays a major role in the government policy. The Bank is considered to be one of the cornerstones of the government of Saudi Arabia. It provides loans for citizens enabling them to contribute to the construction of the country. The objectives of the bank are to provide interest-free loans for small enterprises, employers and emerging trades to encourage them to run their own businesses independently, provide interest-free social loans for citizens with limited incomes in order to help them overcome their financial difficulties, play a coordinating role for MSME sector, encourage savings for individuals and institutions in the Kingdom of Saudi Arabia and find the appropriate tools to achieve this goal.

Saudi enterprises can benefit from this research because the performance of customer management services will undoubtedly contribute to increasing customer satisfaction and improve the process of decision-making. In addition, our investigation will open an opportunity to identify strengths and weaknesses in the management of customer relationship.

\section{METHODOLOGY}

As discussed previously, study proposes a set of service quality items in Saudi Investment Bank. These items have been composed of the review of previous studies in the literature, including the original SERVQUAL model, modified SERVQUAL studies as well as the focus group discussions. Conceptual framework of this research is IBSQ (Islamic Banking Service Quality) model based on proposed items of service quality.

Methodologically, a qualitative research design was determined the best mean to develop a conceptual model depicting the service quality construct within Saudi Arabia context. It well suits for this type of research that tries to understand events regarding management and decision-making in detail. This type of study uses a smaller sample yet it pays much greater attention on the individual case. The drawback might that the results often need to be verified by using quantitative methods (Gummerson, 1999).

This research is conducted using a mix of qualitative and quantitative methods. In order to build a general understanding of Islamic banking and customer needs from Islamic banks, the research first adopts an interpretivism paradigm or qualitative approach presented in discussion groups. Bryman and Bell (2003) state that qualitative research can be used to guide quantitative research in either providing hypotheses or aiding measurement. In this study, a qualitative stage (discussion groups) facilitated the structure and design of the survey questions used in the quantitative stage.

To this end, our research included exploratory and confirmatory research stages. In order to test the cultural stability of the service quality construct, ethnic Saudi within Saudi Arabia were identified as the sample population. Saudi Arabia was selected as a cultural environment broadly displaying different 
cultural characteristics compared to the USA using Hofstede (1984) measures and yet possessing a large middle class in society.

Exploratory, in-depth, semi-structured interviews were conducted to create a conceptual model. The multidimensional instrument developed mainly by Parasuraman et al. $(1985 ; 1988 ; 1990 ; 1991 ; 1993$; 1994) and Othman (2003) is used as a guide to develop the measurement of service quality variables. In addition, the focus group analysis results identified new items of Islamic service quality variables, giving 34 items used in developing SERVQUAL variables for Islamic banks. The items measured respondents' importance, expectations and perceptions. The items are categorized into seven operational groups presented below:

1. Service is measured using four items: bank operates according to Islamic Law, wide range of Islamic products (e.g. Islamic mortgage, Islamic current account), wide range of services (e.g. financial advisor).

2. Convenience is measured using three items: convenient bank location, number of cash machines available, convenient opening hours.

3. Efficiency is measured using four items: short waiting time in bank, bank resolves the problem quickly, speed of transactions, efficient transactions.

4. Communication is measured using three items; clear communication (e.g. clear statement, clear explanation and answers), accurate bank statement and easy bank to deal with.

5. Employees are measured using five items: employees give you individual attention, friendly employees, polite employees, knowledgeable employees, helpful employees.

6. Security is measured using eight items: bank size, well known bank, bank reputation, secure banking, confidentiality of customer information, safe from political action, confidence in bank's management, and confidence in bank's Sharia advisors.

7. Physical attributes are measured using seven items: bank has modern-looking equipment, bank's building has Islamic architecture, separate department or counters for ladies, bank has a prayer room, bank has an Islamic appearance, female staff wears Hijab, closing for Friday prayer time.

As can be seen from Table 1, the key dimensions or factors of Islamic banking service quality identified by customers and potential customers have been labeled in this study according to the nature of their items and their names in previous studies. The factors are labeled: responsiveness, empathy, Islamic tangibles, accessibility and reputation.

The first two factors, responsiveness and empathy, have a significantly greater edge in explaining Islamic banking service quality and are the most important to the surveyed population than the other identified dimensions or factors, including Islamic tangibles, accessibility and reputation. This is indicated by the elative amount of variance in the generated data accounted for each of the revealed factors. As stated above, factor 1 and factor 2 accounted for $16.48 \%$ and $16 \%$ respectively, while factors 3,4 and 5 accounted for $11.57 \%, 10.9 \%$ and $10.08 \%$ respectively.

The five factors have been labeled according to how studies identified each dimension and what each dimension includes. Table 1 shows IBSQ's items and factors. 
Table 1: Description of IBSQ items

\begin{tabular}{|c|c|}
\hline IBSQ Factors & IBSQ Items \\
\hline \multirow[t]{9}{*}{ Responsiveness } & Friendly employees \\
\hline & Polite employees \\
\hline & Helpful employees \\
\hline & Knowledgeable employees \\
\hline & Employees give you individual attention \\
\hline & Speed of transaction \\
\hline & Bank resolves the problem quickly \\
\hline & Efficient transactions \\
\hline & Short waiting time in bank \\
\hline \multirow[t]{11}{*}{ Credibility } & Confidence in bank's Sharia advisors \\
\hline & Bank runs according to Islamic Law \\
\hline & Confidentiality of customer \\
\hline & Secure banking \\
\hline & Accurate bank statement \\
\hline & Confidence in bank management \\
\hline & Safe from political actions \\
\hline & Wide range of Islamic products (e.g. Islamic mortgage, \\
\hline & Islamic current account) \\
\hline & Easy bank to deal with \\
\hline & $\begin{array}{l}\text { Bank reputation } \\
\text { Female staff wear Hijah }\end{array}$ \\
\hline \multirow{5}{*}{ Islamic tangibles } & Female staff wear Hijab \\
\hline & Bank has a prayer room \\
\hline & Closing for Friday prayer time \\
\hline & Separate department and counter for ladies \\
\hline & Bank has an Islamic appearance \\
\hline \multirow[t]{5}{*}{ Accessibility } & Number of cash machines available \\
\hline & Convenient opening hours \\
\hline & Wide range of services(e.g. financial advisor advisor) \\
\hline & Low service charge \\
\hline & Convenient bank location \\
\hline \multirow[t]{4}{*}{ Bank image } & Bank size \\
\hline & Well known bank \\
\hline & Bank's building has an Islamic architecture \\
\hline & Bank has modern looking equipment \\
\hline
\end{tabular}

Data has been collected using questionnaire personally to selected respondents at Saudi Investment Bank. Sampling method used in this study is a combination of purposive sampling and convenience sampling. The questionnaire was created electronically in Survey Monkey and sent to one hundred and fifty potential customers of Saudi Investment Bank in Saudi Arabia. However, only 92 responses were found to be suitable for analysis. The remaining fifty-eight responses could not be used because of some missing answers in the questionnaires. Response rate was Different question types were included among which rating scales, multiple choices and more. The IBSQ (Islamic Banking Service Quality) measures and assesses service quality in Islamic banks. The tool consisting of thirty-four pairs of questions is based on the concept that the difference between a consumer's perceptions and expectations of the service drives the judgement about the quality of service (SERVQUAL approach). The market research group (Parasurman et al., 1994) identified the difference between customers' expectations and perceptions using three possible directions to explain how customers perceive service quality: difference).

1. Quality exceeds expectations (i.e. expectations < perceptions, resulting in a positive $(+)$

2. Quality is acceptable (expectations = perceptions, resulting in a zero difference).

3. Quality is unacceptable or less than satisfactory (expectations > perceptions, resulting in a negative (-) difference and a service quality or satisfaction gap).

Therefore, customers are satisfied if the difference is positive or zero and customers is not satisfied if the difference is negative. 


\section{RESULTS}

\section{DEMOGRAPHIC DATA}

Using five demographic variables (gender, age, education, income, occupation) for the respondents in the sample we can describe the sample of our study. As we can see from Table 2, the total number of male respondents in the sample is 67 ( 72.8 percent) and the total number of female respondents is 25 (27.2 percent). There is clearly some discrepancy between the male and female numbers. This might be because, as researcher found during the distribution of the questionnaires, female respondents tended to be more concerned and interested in the survey than the male respondents.

Table 2: Demographic profile of respondents

\begin{tabular}{lll}
\hline & Frequency & Percent (\%) \\
\hline Age group & 32 & 34.8 \\
$18-25$ & 39 & 42.4 \\
$26-40$ & 21 & 22.8 \\
$41-55$ & & \\
\hline Gender & 67 & 72.8 \\
Male & 25 & 27.2 \\
Female & & \\
\hline Education & 9 & 9.7 \\
High school or less & 55 & 59.7 \\
Bachelor's degree & 28 & 30.4 \\
Master's degree or higher & & \\
\hline Income range & 13 & 14.1 \\
Less than 3,000 SR & 22 & 23.9 \\
3,000-4,999 SR & 31 & 33.7 \\
5,000-9,999 SR & 15 & 16.3 \\
10,000-20,000 & 11 & 11.9 \\
20,000 or more & & \\
\hline Employment & 24 & 26.1 \\
Executive/senior management & 8 & 9 \\
General administration/supervisory & 12 & 13 \\
Self-employed & 16 & 17.4 \\
Technician & 11 & 12 \\
Housewife & 10 & 11 \\
Student/unemployed & 7 & 8 \\
Others & &
\end{tabular}

About 34.8 percent of them were between 18 and 25 years old and 39 respondents (42.4 percent) were between 26 and 40 . More than one fifth of customers were at age range of 41 and 55 years. With regard to the level of education, as Table 2 illustrates, there were 28 respondents in the above degree category (i.e. masters or doctoral qualifications) which represents 30.4 percent of the respondents, while 55 held university bachelor degrees and 74 were in the above secondary school category. Only 9 ( 9.7 percent) of the respondents had high school and no formal qualifications. Thus, 90.1 percent of the respondents were educated. The data on annual income summarized in the table above demonstrates that 11.9 percent of valid responses had high annual incomes (over 20,000 SR), while 16.3 percent had annual income of 10,000 to $20,000 \mathrm{SR}$ and 31 respondents (33.7 percent) earned moderate amount between 5,000 and 9,999 SR. 3,000 to 4,999 SR category were 23.9 percent, 13 had annual income less than 3,000 SR which suggests that they were mostly unemployed people or students. Lastly, the distribution of occupations summarized in Table 2 shows that out of 92 valid responses 26.1 percent are executives and people worked in senior management, 9 percent come from general administration, 12 are selfemployed, 17.4 percent work as technicians, 12 percent is housewives and 7 percent is in other posts, 11 percent of the respondents are students and unemployed. Almost $16 \%$ of the respondents have been using Saudi Investment Bank services for more than 10 years. 29\% of the customers have been using services from $2-5$ years and roughly $34 \%$ for less than a year. 


\section{IBSQ ANALYSIS RESULTS}

Table 3 illustrates the twenty-six service quality items that cause the gap (IBAH customers' dissatisfaction) ranked according to their importance to the customers and potential customers, together with the factors (F1, F2, F3 or F4) to which each item has been allocated. Importance rank has been obtained by respondents' answers; it is the frequencies (valid percentage) of important and very important choices to the twenty-six gap items.

\section{Table 3: Customer dissatisfaction with 26 IBSQ items}

\begin{tabular}{|c|c|c|c|}
\hline & Service quality items & $\begin{array}{c}\text { Very important } \\
\text { and important } \\
(\%)\end{array}$ & Factor \\
\hline 1. & Bank runs according to Islamic law & $96.1 \%$ & F2 \\
\hline 2. & Confidentiality of customer information & $95 \%$ & F2 \\
\hline 3. & Secure banking & $94.7 \%$ & $\mathrm{~F} 2$ \\
\hline 4. & Confidence in bank's Sharia advisors & $94.4 \%$ & $\mathrm{~F} 2$ \\
\hline 5. & Clerk communication & $94.1 \%$ & $\mathrm{~F} 2$ \\
\hline 6. & Knowledgeable employees & $93.8 \%$ & F1 \\
\hline 7. & Easy bank to deal with & $93.6 \%$ & $\mathrm{~F} 2$ \\
\hline 8. & Efficient transactions & $93.3 \%$ & $\mathrm{~F} 1$ \\
\hline 9. & Helpful employees & $93.1 \%$ & $\mathrm{~F} 1$ \\
\hline 10. & Accurate bank statement & $92.9 \%$ & F2 \\
\hline 11. & Bank resolves the problem quickly & $92.7 \%$ & $\mathrm{~F} 2$ \\
\hline 12. & Confidence in bank's management & $92.5 \%$ & $\mathrm{~F} 2$ \\
\hline 13. & Wide range of Islamic products & $92.2 \%$ & F2 \\
\hline 14. & Friendly employees & $90.6 \%$ & F1 \\
\hline 15. & Speed of transaction & $90.3 \%$ & $\mathrm{~F} 1$ \\
\hline 16. & Safe from political action & $88.5 \%$ & $\mathrm{~F} 2$ \\
\hline 17. & Number of cash machine available & $86.3 \%$ & F4 \\
\hline 18. & Convenient bank location & $86.1 \%$ & F4 \\
\hline 19. & Wide range of Islamic services & $85.7 \%$ & $\mathrm{~F} 4$ \\
\hline 20. & Bank reputation & $85.6 \%$ & $\mathrm{~F} 2$ \\
\hline 21. & Short waiting time in bank & $81.4 \%$ & F1 \\
\hline 22. & Closing for Friday prayer time & $78.2 \%$ & F3 \\
\hline 23. & Low service charges & $74.4 \%$ & $\mathrm{~F} 4$ \\
\hline 24. & Female staff wear hijab & $67.8 \%$ & F3 \\
\hline 25. & Bank has a prayer room & $63.5 \%$ & F3 \\
\hline 26. & Separate department for ladies & $60.9 \%$ & F3 \\
\hline
\end{tabular}

\section{Responsiveness (Factor one)}

Factor one (F1) that is "responsiveness" contains nine service quality items, seven of which show customers dissatisfaction. These are: knowledgeable employees ( $93.8 \%$ of customers regard this item as important or very important); efficient transactions (93.3\% regard this as important or very important); helpful employees (93.1\%); bank resolves the problem quickly (92.7\%); friendly employees (90.6\%); speed of transactions $(90.3 \%)$; short waiting time in bank $(81.4 \%)$.

\section{Credibility (Factor two)}

From above table, it can be seen that the larger percentage of items of importance to the customers are among factor 2 (F2), which has been named 'credibility' in this study. Islamic bank account holders are dissatisfied with all service quality items relating to credibility. By using the frequency table of customers' importance ratings for each item, we can assess the extent of customers' satisfaction or dissatisfaction. For instance, item one in factor two (bank runs according to Islamic law) has a statistically significant overall satisfaction gap and $96.1 \%$ of customers regard this item as important or very important.

Hence, customers' dissatisfaction with this item can be confirmed. All the items relating to empathy have results of perceptions lower than expectations yet these items are viewed as being important or very important to the customers. The percentages are as follows: bank runs according to Islamic law $(96.1 \%)$; confidentiality of customer information (95\%); secure banking $(94.7 \%)$; confidence in bank's Sharia advisors $(94.4 \%)$; clear communication (94.1\%); easy bank to deal with (93.6\%); accurate bank statements $(92.9 \%)$; confidence in bank's management $(92.5 \%)$; wide range of Islamic products $(92.2 \%)$; safe from political action $(88.5 \%)$; and bank reputation $(85.6 \%)$. 


\author{
Alshahrani Meshal Saeed S, Alshahrani Bander Sayaf Z, Alshahrani Ahmed Saeed A \\ Does customer service matter? A customer perception of bank services in Islamic countries
}

\title{
Islamic Tangible (Factor three)
}

Factor three (F3), which the study termed "Islamic tangible" has four service quality items deemed to be unsatisfactory and confirmed by the customers importance ratings. These are: closing for Friday prayer time (with an important or very important valid percentage of $78.2 \%$ ); female staff wear hijab (67.8\%); bank has a prayer room (63.5\%); separate department for ladies (60.9\%); Only one item, "bank has Islamic appearance", showed no significant difference between customers' expectations and perceptions, possibly because their expectations have been met or probably their perception is higher.

\section{Accessibility (Factor four)}

Factor four (F4), named 'accessibility', also has four service items with perceptions significantly below expectations and rated as important or very important by customers. The items are; number of cash machines available (86.3\%); convenient bank location $(86.1 \%)$; wide range of Islamic services $(85.7 \%)$; and low service charge (74.4\%). As Islamic banks are working in England they work normal working hours.

$8 \%$ of the respondents are satisfied of how Saudi Investment Bank has developed its range of services, $31 \%$ are satisfied to some extent, 23 of the respondents are not satisfied to some extent, $17 \%$ are not satisfied and $20 \%$ remain neutral. Regarding good customer relations through its services, $29 \%$ of the respondents agree that Saudi Investment Bank is maintaining a satisfactory level of customer relations, $7 \%$ strongly agree, $20 \%$ disagree and $9 \%$ of the respondents strongly disagree while $34 \%$ remain neutral. More than $60 \%$ of the respondents agree and strongly agree that the contribution of Customer Relationship Management is essential in the performance of Saudi Credit bank.

$36 \%$ of the respondents strongly agree that providing employees with the information and processes necessary to know their customers, understand and identify customer needs and effectively build relationships between the company, its customer base and distribution partners is vital, while $58 \%$ agree that helping an enterprise to enable its marketing departments to identify and target their best customers, manage marketing campaigns and generate quality leads for the sales team is very important. $46 \%$ agree that assisting the organization to improve telesales, account and sales management by optimizing information shared by multiple employees and streamlining existing processes (for example, taking orders using mobile devices) is crucial. $44 \%$ of the respondents are of the opinion that allowing the formation of individualized relationships with customers, with the aim of improving customer satisfaction and maximizing profits; identifying the most profitable customers and providing them the highest level of service is decisive.

\section{DISCUSSION}

Current research was intended to explore the perception of service quality of Saudi Investment Bank customers in Saudi Arabia. A profile analysis of Saudi Investment Bank clients was conducted. Moreover, customer awareness of Saudi Investment Bank products and services, their usage of those services and their satisfaction were also examined. Lastly, the Islamic Banking Service Quality items were used by Saudi Investment Bank in order to measure customers perception of service quality. The results of the study illustrates that the majority of Islamic bank customers are well educated, with approximately 59.7 per cent holding a bachelor degree, and about 30.4 per cent holding a master's degree or above. Furthermore, the results also show that about 77.2 per cent of Saudi Investment Bank customers fall between 18-40 years. Rust et al. (1994) noticed in his work that understanding of the concept of satisfaction is necessary for managing service quality effectively. Satisfaction roughly defined as "enough" or "enough to excess" (Oliver, 1993). Therefore, customer satisfaction can be described as the customer's fulfillment response. It has also been described as a process by (Rust, et al., 1994) and the most broadly accepted of process theories is that of expectancy disconfirmation in which satisfaction is viewed as largely based on meeting or exceeding expectations. The characteristics discussed in the introduction make the concept of quality in service different from in manufacturing goods. That means quality should be a yardstick of customer satisfaction in services. Therefore, a bank that devoted to provide high quality service must follow consistent customer satisfaction. However, adopting service quality effectively in Islamic banking management requires a clear understanding of what service quality means to their customers. Consequently, Islamic bank management must measure the overall customers' satisfaction and understand the nature of service quality and customer value and how these features interact.

This research also assists further testing of the validity of the CARTER model by adding three questions to the survey: Overall satisfaction, Satisfaction with personal contact and Satisfaction with service quality. The results were shown in Table 4. 
Table 4: Customer Satisfaction in Saudi Investment Bank

\begin{tabular}{llc}
\hline Satisfaction questions & Average importance & [mportance Percentage \\
\hline Overall & 3.73 & 63.6 \\
Personal interaction with staff & 3.61 & 52 \\
Service quality & 3.48 & 59.4 \\
\hline
\end{tabular}

Table 4 demonstrates that Saudi Investment Bank's level of overall satisfaction and personal contacts with staff were 63.6 and 52 percent respectively. That means the bank is not doing well to satisfy its customers. Moreover, more than 59 percent of respondents stand in a dissatisfied or neutral position with regard to quality services. Thus, Saudi Investment Bank should build quality culture by adapting a quality system in its managerial and operational sides.From survey results, we can see that Saudi Investment Bank has not implemented or adapted quality system or program since its foundation. There is no department responsible for quality measure and control in organization. Therefore, quality knowledge and practice should be fostered in both operational and managerial levels. Accordingly, we can give following recommendations to improve service quality and performance in the organization:

- The potential of Islamic banks depends on having the highly qualified managers, devoted to the accomplishment of this bank. Expertise and ability to compete are key elements for prosperous relationships with Saudi Investment bank customers. Training programs might demonstrate to be a practical tool for cultivating the executive capabilities of Saudi Investment Bank personnel.

- It is essential for Saudi Investment Bank to create and put into practice feasible service quality programs. Lack of the wide range and the proper quality of the services will certainly create problems in keeping their present clients and reach new ones. Therefore, Saudi Investment Bank may find it useful to observe the practices of successful banks so as to design their programs for enhancing the quality of their services.

- Bank administration should introduce quality initiative and programs to decision, departments, and branch mangers, through them to all the staff in the bank, and discuss it in the planned meetings.

- Quality teams must conduct employees 'and customers' satisfaction surveys from time to time and when they believe it is satisfactorily improved.

\section{CONCLUSION}

The previous discussions illustrate a change of customers' perceptions towards state of service. In current research, the most important customers' concerns are represented by factor called credibility. Customers tend to trust and give better evaluation if bank runs according to Islamic law; there is confidentiality of customer information, secure banking, wide range of Islamic products and convenience to deal with a bank. Since survey showed wide variance of answers, it is essential for banks to give a thought to conduct SWOT analysis in order to find and work on weak areas. In recent literature, scholars claim that greater satisfaction of customer helps to retain customer, particularly, in greatly competitive and enriched market place, such as in economic services provided by the finance industry (Rust and Zahorik, 1993; Trubik and Smith, 2000). Moreover, in the present competitive financial service industry, majority of the banks provide similar or identical products in the world and service quality is an important criteria to differentiate themselves in the market environment. Therefore, in order to be successful, banks must offer service to their customers that satisfy or surpasses their expectations and the current study delivers some helpful recommendations to the bank policy makers which can help them to make accurate decision to increase the quality of services, particularly in Saudi Arabia. Obviously, the present investigation gives idea of the relationship among customer services, customer satisfaction and customer perception.In nowadays' competitive market place and as a response to the quality thrust and the goal of the country to compete globally, we think that it is must for the administration of the banks to correctly investigate their corporate quality programs and customer service system. Moreover, it is necessary for them to consider that their performance actions have to provide a value on better approach to customer requirements. These measures and changes can increase expenses of the company, in terms of worker effort and time, however the management of banks needs to find ways to effectively overcome these challenges in present turbulent times. In the end, we can say that this exploratory study examines only one bank in specific region in Saudi Arabia, implying a need for additional research applying this combined model and other methods to investigate private banking in the mass affluent segment. 


\section{REFERENCES}

- Al-Sultan, W. (1999). Financial characteristics of interest-free banks and conventional banks.

- Al-Tamimi, H. A. H. and Al-Amiri, A. (2003). Analyzing service quality in the UAE Islamic banks. Journal of Financial Services Marketing, 8(2), 119-132.

- Bennett, D. and Higgins, M. (1988). Quality means more than smiles. ABA Banking journal, 80(6), 46.

- Bitran, G. and Lojo, M. (1993). A framework for analyzing the quality of the customer interface. European Management Journal, 11(4), 385-396.

- Bowen, J. W. and Hedges, R. B. (1993). Increasing service quality in retail banking. Journal of Retail Banking, 15, 21-21.

- $\quad$ Bryman, A. Bell. E.,(2003), Business research methods.

- Cavusgil, S. T. and Das, A. (1997). Methodological issues in empirical cross-cultural research: A survey of the management literature and a framework. MIR: Management International Review, 7196.

- Chen, I. J. and Popovich, K. (2003). Understanding customer relationship management (CRM) People, process and technology. Business process management journal, 9(5), 672-688.

- Coskun, A. and Frohlich, C. J. (1992). Service: the competitive edge in banking.Journal of Services Marketing, 6(1), 15-22.

- Dabholkar, P. A. (1996). Consumer evaluations of new technology-based self-service options: an investigation of alternative models of service quality. International Journal of research in Marketing, 13(1), 29-51.

- Donthu, N. and Yoo, B. (1998). Cultural influences on service quality expectations. Journal of service research, 1(2), 178-186.

- El-Din, S. E. I. T. and Shahril, R. A. M. (2007). Analysis of banking service quality perception: a comparative study for Islamic and conventional banks. In IIUM International Conference on Islamic Banking and Finance, Kuala Lumpur.

- Furrer, O., Liu, B. S. C. and Sudharshan, D. (2000). The relationships between culture and service quality perceptions basis for cross-cultural market segmentation and resource allocation. Journal of service research, 2(4), 355-371.

- Ghobadian, A., Speller, S. and Jones, M. (1994). Service quality: concepts and models. International Journal of Quality and Reliability Management, 11(9), 43-66.

- Hegazy, I. A. (1995). An empirical comparative study between Islamic and commercial banks' selection criteria in Egypt. International journal of Commerce and Management, 5(3), 46-61.

- Hofstede, G. (1984). Culture's consequences: International differences in work-related values (Vol. 5).

- Jamal, A. and Naser, K. (2003). Factors influencing customer satisfaction in the retail banking sector in Pakistan. International Journal of Commerce and Management, 13(2), 29-53.

- Julian, C. C. and Ramaseshan, B. (1994). The role of customer-contact personnel in the marketing of a retail bank's services. International Journal of Retail and Distribution Management, 22(5), 2934.

- Metawa, S. A. and Almossawi, M. (1998). Banking behavior of Islamic bank customers: perspectives and implications. International Journal of Bank Marketing, 16(7), 299-313.

- Narayana, C. T. S. and Ramesh, R. (2012). Customer Relationship Management in Banking Sector-A Comparative Study. KKIMRC IJRHRM, 1(2), 20-29.

- Othman, A. Owen, Lynn, (2002),"Adopting and Measuring Customer Service Quality (SQ) in Islamic Banks". International Journal of Islamic Financial Services, 3(1), 158-193.

- Parasuraman, A. and Grewal, D. (2000). The impact of technology on the quality-value-loyalty chain: a research agenda. Journal of the academy of marketing science, 28(1), 168-174.

- Plakoyiannaki, E. and Tzokas, N. (2002). Customer relationship management: A capabilities portfolio perspective. The Journal of Database Marketing, 9(3), 228-237.

- Reinartz, W., Krafft, M. and Hoyer, W. D. (2004). The customer relationship management process: Its measurement and impact on performance. Journal of marketing research, 41(3), 293-305.

- Shafie, S., Azmi, W. N. W. and Haron, S. (2004). Adopting and measuring customer service quality in Islamic banks. Journal of Muamalat and Islamic Finance Research, 1(1), 1-12.

- Srivastava, R. K., Shervani, T. A. and Fahey, L. (1999). Marketing, business processes and shareholder value: an organizationally embedded view of marketing activities and the discipline of marketing. The Journal of Marketing, 168-179.

- Wakefield, K. L. and Blodgett, J. G. (1999). Customer response to intangible and tangible service factors. Psychology and Marketing, 16(1), 51-68.

- Winsted, K. F. (1997). The service experience in two cultures: A behavioral perspective. Journal of Retailing, 73(3), 337-360.

- $\mathrm{Xu}$, M. and Walton, J. (2005). Gaining customer knowledge through analytical CRM. Industrial management and data systems, 105(7), 955-971. 
Alshahrani Meshal Saeed S, Alshahrani Bander Sayaf Z, Alshahrani Ahmed Saeed A

Does customer service matter? A customer perception of bank services in Islamic countries

- $\quad \mathrm{Xu}$, Y., Yen, D. C., Lin, B. and Chou, D. C. (2002). Adopting customer relationship management technology. Industrial management and data systems, 102 (8), 442-452.

- Zablah, A. R., Bellenger, D. N. and Johnston, W. J. (2004). An evaluation of divergent perspectives on customer relationship management: Towards a common understanding of an emerging phenomenon. Industrial marketing management, 33(6), 475-489. 